\title{
Investigation of stress-strain models for confined high strength concrete
}

\author{
METIN HUSEM* and SELIM PUL \\ Karadeniz Technical University, Department of Civil Engineering, 61080 \\ Trabzon, Turkey \\ e-mail: mhusem@ktu.edu.tr
}

MS received 17 March 2006; revised 25 September 2006

\begin{abstract}
The effects of confinement reinforcement on the behaviour of high strength concrete columns are investigated for which prismatic experimental specimens were prepared. In the experiment specimens, four longitude reinforcement and confinement reinforcement were used. For each experiment, stress-strain relationship of concrete was obtained and compared with models proposed earlier. The results show that confinement reinforcement improved the ductility of high strength concrete. The ascending branch of stress-strain curves depended on the ratio of confinement reinforcement was similar to the modified Kent-Park model and the descending branch similar to the Nagashima model.
\end{abstract}

Keywords. High strength concrete; confined concrete; stress-strain models; ductility toughness.

\section{Introduction}

Concrete commonly used in engineering structures is defined as a composite material produced using cement, aggregate, water and chemical and mineral admixture materials when necessary. The strength and durability of concrete has undergone continuous improvement over the years and these improved materials are now commonly used. The definition of high strength concrete has changed with time, region and the production technology used. For example, in the 1950s, concrete having $34 \mathrm{MPa}$ characteristic compressive strength was considered as high strength. In the 1960s, the concrete produced in USA had compressive strength between 41 and $52 \mathrm{MPa}$. In the early 1970s, the compressive strength went up further to $62 \mathrm{MPa}$. Recently, concrete having 80-100 MPa compressive strength has been used in reinforced concrete and pre-stressed concrete structures. Currently, high strength concrete with $250 \mathrm{MPa}$ compressive strength is produced using high strength aggregate.

Today, high strength concrete is used in off-shore platforms, sea structures, high-rise buildings and bridges. One of its advantages is the lessening column cross-sectional areas. It was found that using high strength concrete in multi-storey, high-rise buildings is economical. However, using high strength concrete in building columns in seismic areas poses some problems. The high strength concrete has less ductility compared to ordinary concrete. It was 
reported that using fibre in concrete raises ductility (Campione \& Miraglia 2003; Nagarajah 1987; Eurocode 8 2003).

In seismic areas, to prevent sudden failures of building columns due to the effect of earthquake and to have ductility behaviour, seismic codes rules have been recommended (FEMA 368-369 2001; IBC 2003).

Several experimental and theoretical investigations concerned with calculating the strength and ductility of compressed ordinary concrete elements with confinement steel reinforcement and having circular or rectangular transverse cross-section have been reported. The effect of confinement reinforcement on stress-strain relationship of the concrete was first determined by Considere (1903). Modelling this effect was studied by Richart et al (1928, 1929). Balmer (1949) improved the analytical model proposed by Richart et al. In their studies, King (1946) and Blume et al (1961) investigated confinement reinforcement in reinforced concreted rectangular section instead of circular section. Based on small scale specimens, Roy \& Sozen (1964), Soliman \& Yu (1967) and Sargin (1971) proposed a different stress-strain relationship for confinement concrete. Kent \& Park (1971) proposed a model depending on their previous studies. Park et al (1982), Saatcioglu \& Razvi (1992), Sheikh \& Uzumeri (1980, 1982), Sheikh \& Yeh (1990), Mander et al (1988), Ahmad \& Shah (1982) and Chung et al (2002) were those who proposed stress-strain models depending on test results. Studies on high strength concrete are limited compared to ordinary concrete Mugurama et al (1983), Nagashima et al (1992), Galeota et al (1992), Hsu \& Hsu (1994), Cusson \& Paultre (1995), Yong et al (1988) and Fafitis \& Shah (1985).

In this study, the effects of confinement reinforcement on the bahaviour of high strength concrete columns were investigated. For this purpose, prismatic experimental specimens were prepared. These average strength of the specimens was more than $60 \mathrm{MPa}$, their crosssections $150 \mathrm{~mm} \times 150 \mathrm{~mm}$, and their heights $300 \mathrm{~mm}$. In these specimens, four longitude reinforcements at $10 \mathrm{~mm}$ diameter and confinement reinforcement having $8 \mathrm{~mm}$ diameter at $50 \mathrm{~mm}, 75 \mathrm{~mm}, 100 \mathrm{~mm}, 150 \mathrm{~mm}$ and $300 \mathrm{~mm}$ spacing were used. For each experiment, stress-strain relationship of concrete was obtained. The values obtained were compared with the models proposed earlier (Kent \& Park 1971), Saatcioglu \& Razvi 1992), Mugurama et al (1983) and Nagashima et al (1992). The ascending branch of stress-strain curves depends on the ratio of confinement reinforcement and was similar to the modified Kent \& Park model proposed by Park et al (1982) and the descending branch was similar to the model of Nagashima et al (1992). In addition, the decrease of confinement reinforcement spacing caused maximum 19\% increase in compressive strength. On the other hand, it increased ductility to a large extent.

\section{Experimental study}

\subsection{Properties of materials used}

Limestone aggregate was used in producing high strength concrete. The maximum aggregate size was $16 \mathrm{~mm}$. Some properties of this aggregate are given in table 1 . The average compressive strength was obtained by taking core specimens having $75 \mathrm{~mm}$ diameter and $150 \mathrm{~mm}$ height from rocks used for producing aggregates.

High strength concrete was produced using PC42.5 (CEM I) cement (the number 42.5 denotes its characteristic compressive strength in $\mathrm{MPa}$ ). Some properties of this cement are given in table 2. In the production of high strength concrete, silica fume and ASTM C-494 F type super plasticizer water-reducing admixtures were used. 
Table 1. Some physical and mechanical properties of aggregate.

\begin{tabular}{|c|c|c|c|c|}
\hline \multicolumn{3}{|l|}{ Physical properties } & \multicolumn{2}{|c|}{ Mechanical properties } \\
\hline $\begin{array}{l}\text { Aggregate } \\
\text { size }(\mathrm{mm})\end{array}$ & $\begin{array}{l}\text { Density } \\
\left(\mathrm{kg} / \mathrm{m}^{3}\right)\end{array}$ & Water absorption (\%) & $\begin{array}{l}\text { Specimen } \\
\text { size }(\mathrm{mm})\end{array}$ & $\begin{array}{c}\text { Compressive } \\
\text { strength (MPa) }\end{array}$ \\
\hline $\begin{array}{l}\text { Fine }(<4 \mathrm{~mm}) \\
\text { Course }(<4 \mathrm{~mm})\end{array}$ & $\begin{array}{l}2671 \\
2706\end{array}$ & $\begin{array}{l}0.52 \\
0.42\end{array}$ & $\begin{array}{c}\phi 75 \mathrm{~mm} \\
h=150 \mathrm{~mm}\end{array}$ & 83 \\
\hline \multicolumn{5}{|c|}{$\phi$ : specimen diameter, $h=$ specimen height } \\
\hline
\end{tabular}

Table 2. Some physical and mechanical properties of cement.

\begin{tabular}{|c|c|c|c|c|c|}
\hline \multicolumn{3}{|c|}{ Physical properties } & \multicolumn{3}{|c|}{ Mechanical properties } \\
\hline Density $\left(\mathrm{g} / \mathrm{cm}^{3}\right)$ & & $3 \cdot 10$ & $\begin{array}{l}\text { Age } \\
\text { (day) }\end{array}$ & $\begin{array}{c}\text { Flexural } \\
\text { strength }(\mathrm{MPa})\end{array}$ & $\begin{array}{c}\text { Compressive } \\
\text { strength (MPa) }\end{array}$ \\
\hline $\begin{array}{l}\text { Specific surface } \\
\text { (Blaine) } \mathrm{cm}^{2} / \mathrm{g}\end{array}$ & & 3680 & 2 & $5 \cdot 75$ & $29 \cdot 05$ \\
\hline \multirow{2}{*}{$\begin{array}{l}\text { Setting } \\
\text { time (vicat) }\end{array}$} & $\begin{array}{l}\text { Initial } \\
\text { (hours) }\end{array}$ & $2 \cdot 10$ & 7 & 7.55 & 43.65 \\
\hline & & $4 \cdot 15$ & 28 & $8 \cdot 75$ & $52 \cdot 97$ \\
\hline
\end{tabular}

In the production of confined high strength concrete experiment specimens, longitude reinforcement ( $10 \mathrm{~mm}$ dia) and confinement reinforcement ( $8 \mathrm{~mm}$ dia) were used. Some mechanical properties of these reinforcements are given in table 3 .

\subsection{Properties of specimens}

Confined concrete prismatic experimental specimens were produced using four longitude reinforcements (10 $\mathrm{mm}$ dia). In these specimens confinement reinforcement diameter was $8 \mathrm{~mm}$. The specimens had $150 \mathrm{~mm} \times 150 \mathrm{~mm}$ cross-section in area and $300 \mathrm{~mm}$ in height. Experimental specimens were produced using different $(50,75,100,150,300 \mathrm{~mm})$ confinement reinforcement spacing. Prismatic experiment specimens without confinement reinforcement were also used. A total of 36 prismatic specimens ( 6 for each series) were prepared. In order

Table 3. Some properties of reinforcements.

\begin{tabular}{rccc}
\hline Reinforcement size $(\mathrm{mm})$ & $\begin{array}{c}\text { Yield } \\
\text { strength (MPa) }\end{array}$ & $\begin{array}{c}\text { Ultimate tension } \\
\text { strength (MPa) }\end{array}$ & $\begin{array}{c}\text { Elongation at } \\
\text { fracture (\%) }\end{array}$ \\
\hline 8 & 330 & 480 & $18 \cdot 4$ \\
10 & 360 & 530 & $21 \cdot 3$ \\
\hline
\end{tabular}


Table 4. The gradation of aggregate used in producing concrete and confined concrete.

\begin{tabular}{lc}
\hline Gradation class $(\mathrm{mm})$ & total weight in percentage \\
\hline $0-0 \cdot 25$ & 4 \\
$0 \cdot 25-0 \cdot 50$ & 4 \\
$0 \cdot 50-1 \cdot 00$ & 5 \\
$1 \cdot 00-2 \cdot 00$ & 12 \\
$2 \cdot 00-4 \cdot 00$ & 20 \\
$4 \cdot 00-8 \cdot 00$ & 25 \\
$8 \cdot 00-16 \cdot 00$ & 30 \\
\hline
\end{tabular}

to determine concrete strength and control reproduction, 36 standard cylinder specimens with $150 \mathrm{~mm}$ diameter and $300 \mathrm{~mm}$ height (6 for each series) were used.

\subsection{Mixture and production}

The proportion of aggregate used in producing concrete and confined concrete is given in table 4. The mix design of concrete is shown in table 5. After weighing the cement, silica fume and all types of granulometric saturated aggregate, they were placed in the concrete mixer for 3 minutes and then dried. Cement and silica fume were then added and mixed for 3 min by adding water and super plasticizer water-reducing admixtures. The concrete thus produced was placed in a standard cylinder and prismatic moulds in three stages. The concrete was placed after vibration for 15 seconds. The specimens were taken out of their moulds a day later and kept in water at $22^{\circ} \mathrm{C} \pm 2{ }^{\circ} \mathrm{C}$ for 21 days. Until the experiment, they were kept at $23^{\circ} \mathrm{C} \pm 2{ }^{\circ} \mathrm{C}$ temperature and $65 \%$ relative humidity. The specimens were 28 -day-old at the time of the experiment.

\section{Results and discussion}

Before starting the experiments, the top and bottom surfaces of test specimens were smoothed. The compressive strength of the specimens thus prepared was determined. Experimental results are shown in table 6 and typical failure patterns of specimens in figure 1. In addition, during uniaxial compressive test horizontal strain under compression using strain gauges (type TML-PL90) was measured. The measurement length of these strain-gauges was $90 \mathrm{~mm}$.

Table 5. The mix design of concrete.

\begin{tabular}{ccccccc}
\hline & & & & & \multicolumn{2}{c}{ Admixtures } \\
\cline { 5 - 7 } W/C & $\begin{array}{c}\text { Cement } \\
\left(\mathrm{kg} / \mathrm{m}^{3}\right)\end{array}$ & $\begin{array}{c}\text { Water } \\
\left(\mathrm{kg} / \mathrm{m}^{3}\right)\end{array}$ & $\begin{array}{c}\text { Total } \\
\text { aggregate }\left(\mathrm{kg} / \mathrm{m}^{3}\right)\end{array}$ & $\begin{array}{c}\text { Absorbed } \\
\text { water }\left(\mathrm{kg} / \mathrm{m}^{3}\right)\end{array}$ & $\mathrm{SP}\left(\mathrm{kg} / \mathrm{m}^{3}\right)$ & $\mathrm{SF}\left(\mathrm{kg} / \mathrm{m}^{3}\right)$ \\
\hline 0.30 & 500 & 150 & 1785 & 4.66 & 16.5 & 50 \\
\hline
\end{tabular}

SP: Superplasticizer admixture,

SF: Silica fume 
Table 6. The characteristic compressive strength of concrete and confined concrete.

\begin{tabular}{lccccc}
\hline & $\begin{array}{c}\text { Cylinder concrete } \\
\text { specimens }\end{array}$ & \multicolumn{4}{c}{ Prismatic concrete and confined concrete specimens } \\
\cline { 2 - 6 } Series & $f_{c c}(\mathrm{MPa})$ & $s(\mathrm{~mm})$ & $\rho_{s}$ & $f_{c p},(\mathrm{MPa})$ & $f_{c p}$ (conf)/ $f_{c p}$ (unconf.) \\
\hline 1 & 64.5 & unconf. & 0 & 64.2 & 1.00 \\
2 & $64 \cdot 2$ & 50 & $0 \cdot 0308$ & $76 \cdot 4$ & $1 \cdot 19$ \\
3 & 64.6 & 75 & $0 \cdot 0205$ & $73 \cdot 8$ & $1 \cdot 15$ \\
4 & 64.4 & 100 & 0.0154 & 72.4 & 1.13 \\
5 & 64.7 & 150 & 0.0103 & 67.3 & 1.05 \\
6 & 64.4 & 300 & $0 \cdot 0051$ & 65.5 & 1.04 \\
\hline
\end{tabular}

$f_{c c}$ : Characteristic compressive strength of standard cyclinder specimens.

$s$ : Confinement reinforcement space. $\rho_{s}$ : Volumetric ratio of confinement reinforcement. $f_{c p}$ : Characteristic compressive strength of prismatic concrete and confined concrete specimens.

The standard cylinder concrete specimens for all series produced in this study have a characteristic compressive strength of $64.5 \mathrm{MPa}$. Besides, the difference between characteristic compressive strength of prismatic experiment specimens produced without using confinement reinforcement and compressive strength of standard cylinder concrete was $0.5 \%$.

In high strength concrete thus produced in this study, when confinement reinforcement ratio increased the compressive strength of concrete increased $19 \%$ compared to compressive strength of specimens without confinement reinforcement. However, the confinement reinforcement space decreased.

The stress-strain curve obtained from the experiments on standard cylinder concrete specimens is given in figure 2. Standard cylinder concrete experimental specimens suddenly failed when they reached their ultimate carrying capacity. Because of this, the descending branch of stress-strain curve on standard cylinder could not be determined in any of these specimens. The strain at ultimate carrying capacity was measured as 0.0026 .
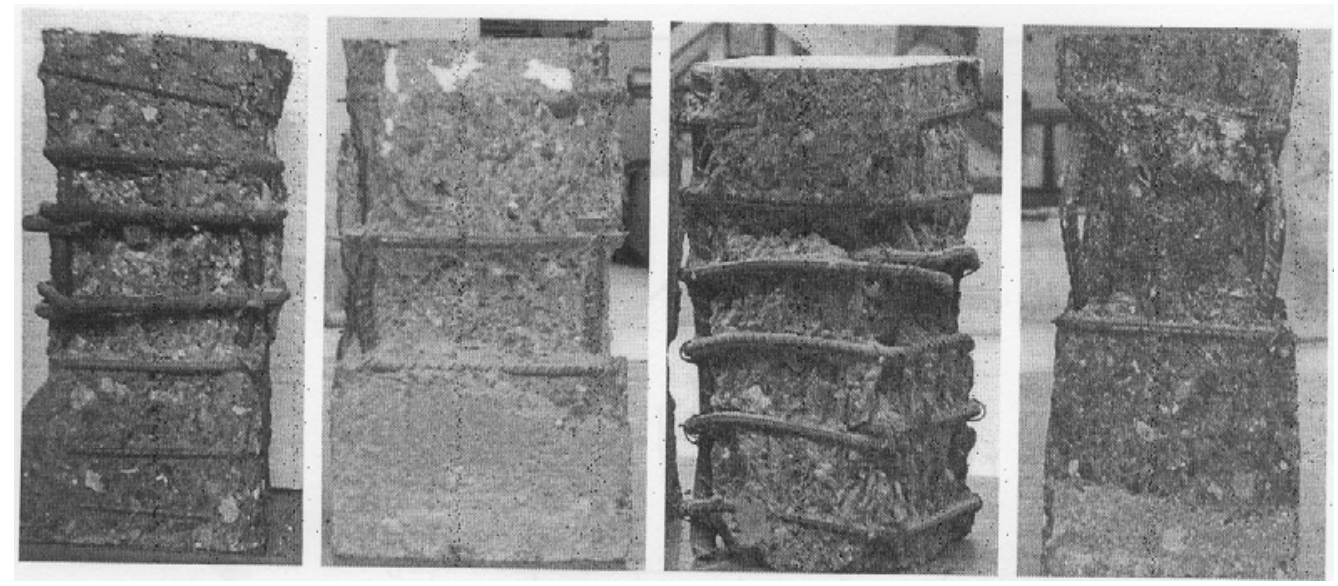

Figure 1. The typical failure patterns of confined concrete specimens. 


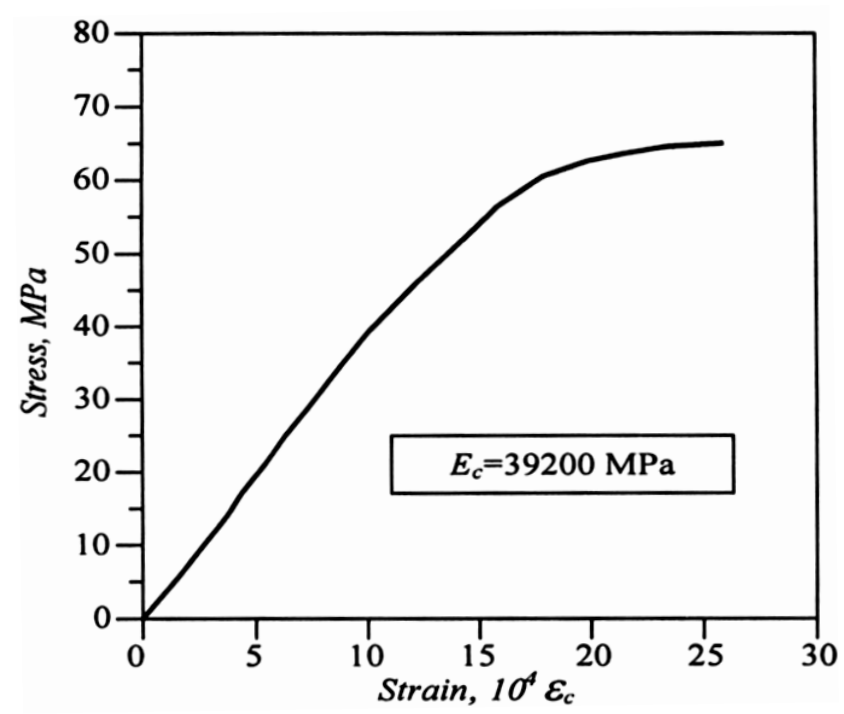

Figure 2. The stress-strain curve of standard cylinder specimens.

Stress-strain curves obtained from prismatic experimental concrete and confined concrete specimens depend on confinement reinforcement spacing are given in figure 3 along with the models proposed by other researchers. The values of ductility and toughness determined from experimental stress-strain curves are given in table 7 . The capacity of energy absorption is indicated in figure 4.

The ascending branch of experimental stress-strain curves for the concrete with $50 \mathrm{~mm}$ confinement reinforcement spacing agree with the modified Kent \& Park model proposed for ordinary concrete. However, in the modified Kent \& Park model more ultimate load was obtained than experimental ultimate load. The descending branch of experimental stressstrain curves agrees with that of the Nagashima et al (1992) model proposed for high strength concrete. The models proposed by Saatcioglu \& Razvi (1992) for ordinary concrete and by Mugurama et al (1983) for high strength concrete had a difference of about $60-70 \%$ in ultimate strength. Experimental ultimate load was $4 \%$ smaller than the load obtained from these models (figure 3).

Experimental stress-strain curves of concrete with $75 \mathrm{~mm}$ confinement reinforcement space were similar to the model proposed by Nagashima et al (1992) for high strength concrete. The compressive strength obtained by Nagashima et al (1992) was 3\% lower than those obtained from our experiments. The stress-strain curves obtained from the modified Kent \& Park model proposed for ordinary concrete agreed with our values for ascending branch. The models proposed by Saatcioglu \& Razvi (1992) and Mugurama et al (1983) had results different from other models (figure 3 ).

The ascending branch of experimental stress-strain curves for the concrete with $100 \mathrm{~mm}$ confinement reinforcement spacing is in harmony with the modified Kent \& Park model proposed for ordinary concrete. Similarly, the descending branch of stress-strain curves obtained experimentally agree with that of Nagashima et al (1992) for high strength concrete. The models proposed by Saatcioglu \& Razvi (1992) for ordinary concrete and Mugurama et al (1983) for high strength concrete had a difference of up to 50-60\% of ultimate strength. The compressive strength obtained from these models was $6 \%$ lesser than experimental compressive strength (figure 3 ). 

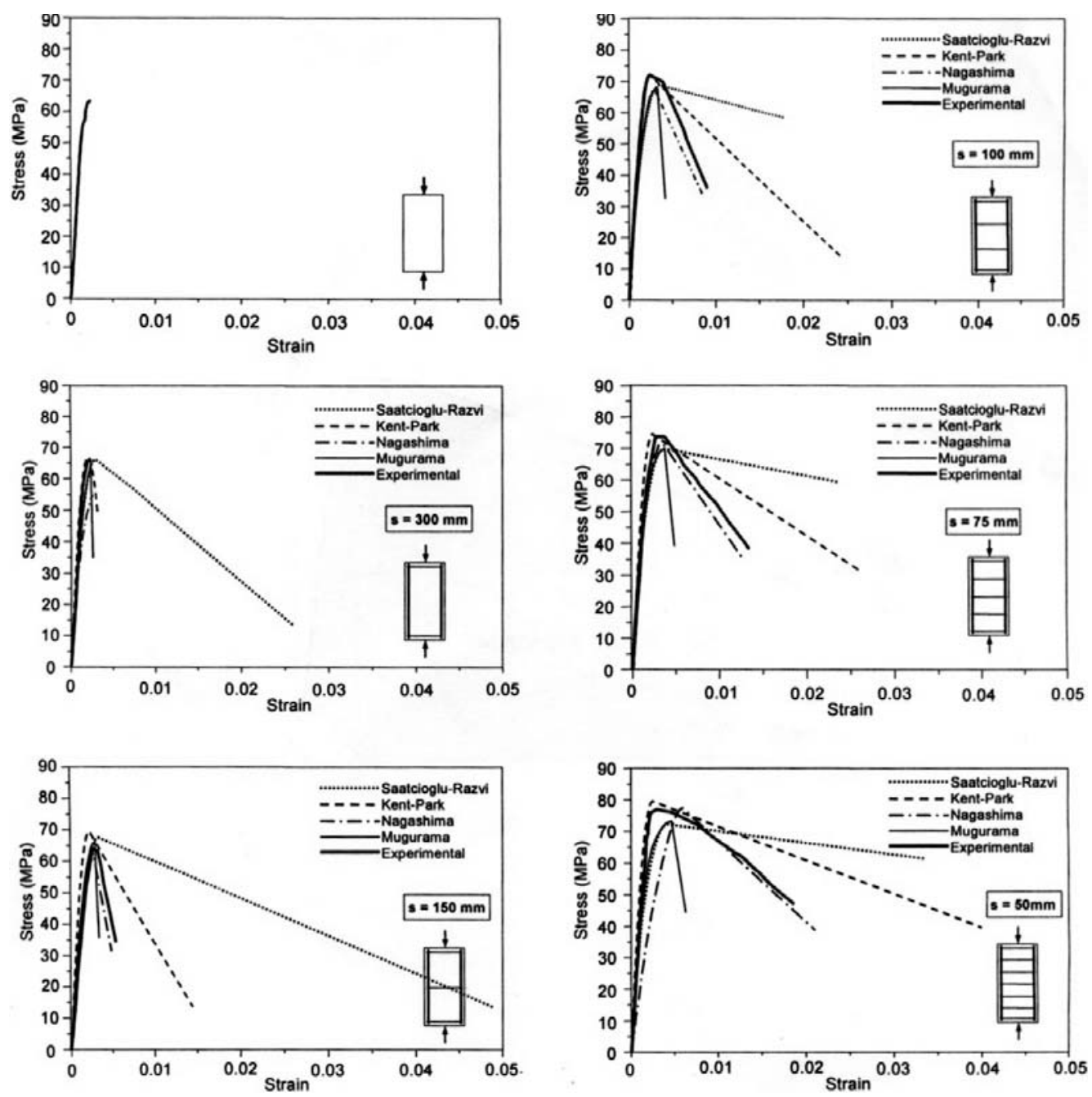

Figure 3. The stress-strain curves of confined concrete and some models.

Table 7. The ductility and toughness ratio of high strength confined concrete.

\begin{tabular}{lcc}
\hline Conf. reinforcement spaces, $s(\mathrm{~mm})$ & Ductility $\left(\mu_{\varepsilon u}=\varepsilon_{c u} / \varepsilon_{c c}\right)$ & Toughness ratio $s / s_{50}$ \\
\hline 50 & $8 \cdot 27$ & $1 \cdot 00$ \\
75 & 4.90 & $0 \cdot 64$ \\
100 & $4 \cdot 17$ & $0 \cdot 43$ \\
150 & $2 \cdot 15$ & $0 \cdot 21$ \\
300 & - & - \\
\hline
\end{tabular}

$\varepsilon_{c u}$ : Ultimate strain

$\varepsilon_{c c}:$ strain at peak stress 


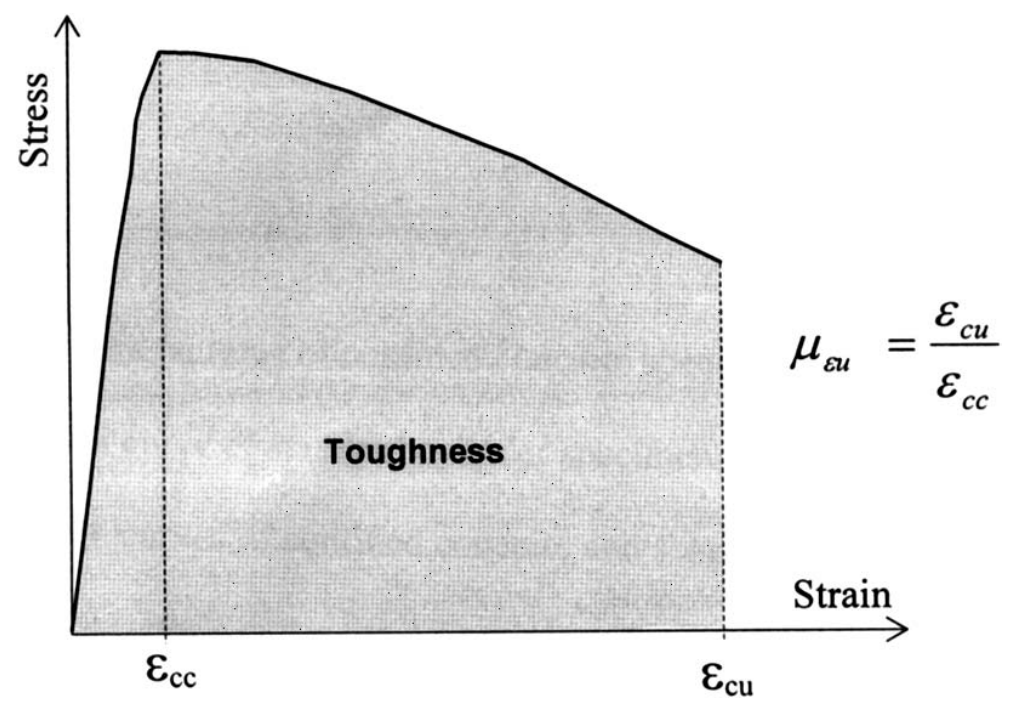

Figure 4. The typical stress-strain curve for determining ductility and toughness.

The ascending branch of experimental stress-strain curves for the concrete with $150 \mathrm{~mm}$ confinement reinforcement spacing had a behaviour similar to the model of Saatcioglu \& Razvi (1992) proposed for ordinary concrete and of Nagashima et al (1992) and Mugurama et al (1983) for high strength concrete. The descending branch of stress-strain curves obtained experimentally agrees with that of Nagashima et al (1992) for high strength concrete. The models Kent \& Park model proposed for ordinary concrete had a difference of $50 \%$ in ultimate strength. In this model, the compressive strength was $3 \%$ lesser than experimental compressive strength (figure 3 ).

The ascending branch of experimental stress-strain curves for concrete with $300 \mathrm{~mm}$ confinement reinforcement spacing was in harmony with the modified Kent \& Park model for ordinary concrete. When experimental specimens reach an ultimate strength, the concrete between confinement reinforcement exploded and scattered, because of this the descending branch of stress-strain curve could not be determined. Models proposed by Saatcioglu \& Razvi (1992) for ordinary concrete and by Nagashima et al (1992) and Mugurama et al (1983) for high strength concrete had a difference approximately of 30\% in ultimate strength. With this confinement reinforcement spacing, the compressive strength obtained from the model proposed by Nagashima et al (1992) was $20 \%$ lesser than experimental compressive strength. But, in our experiments, because of this confinement reinforcement spacing, sudden failure occurred in experimental specimens. The model proposed by Nagashima et al (1992) had the same breaking so the descending branch of stress-strain curve could not be determined.

Ductility ratios obtained from stress-strain curves of experimental specimens which have $50 \mathrm{~mm}$ confinement reinforcement spacing were $68 \%$, 99\% and $386 \%$ and higher than ductility ratios of experiment specimens which have $75 \mathrm{~mm}, 100 \mathrm{~mm}$ and $150 \mathrm{~mm}$ confinement reinforcement spacing. As a result, when confinement reinforcement spacing is decreased, high strength concrete gained ductility to a great extent. The capacity of energy absorbing (toughness) determined by calculating the area under experimental stress-strain curves increased when confinement reinforcement spacing is decreased. The results show that if high 
strength concrete is used in seismic areas buildings, earthquake behaviours can be improved by lowering the confinement reinforcement spacing.

\section{Conclusions}

The ascending branch of experimental stress-strain curves was more convenient to ascending branch of stress-strain curves of the modified Kent \& Park model for ordinary concrete than other models. Descending branch was more convenient to the model proposed by Nagashima et al for high strength concrete.

In the high strength concrete which is more brittler than ordinary concrete, using confinement reinforcement, ductility is increased to a great extent. When confinement reinforcement spacing is decreased to half, ductility improved twice. As a result, by decreasing confinement reinforcement spacing, the earthquake behaviour of high strength concrete can be improved. Decreasing confinement reinforcement spacing has increased the compressive strength of confined concrete to a maximum of $19 \%$.

\section{References}

Ahmad S H, Shah S P 1982 Stress-strain curves of concrete confined by spiral reinforcement. J. Am. Concret. Inst., 79: 484-490

Balmer G G 1949 Shearing strength of concrete under high triaxial stress-computation of Mohr's envelope as a curve. Structural Research Laboratory, Denver, Colorado SP-23 US

Blume J A, Newmark N M, Corning L H 1961 Design of multi-story reinforced concrete buildings for earthquake motions. Portland Cement Association, Chicago, US. 318

Campione G, Miraglia N 2003 Strength and strain capacities of concrete compression members reinforced with FRP. Concrete \& Concrete Composites, 25: 31-41

Chung H S, Yang K H, Lee Y H, Eun H C 2002 Stress-strain curve of laterally confined concrete. Eng. Struct., 24: 1153-1163

Considere A 1903 Experimental researches on reinforced concrete. Translated and Arragged by Leon S. Moisseiff, New York, McGraw

Cusson D, Paultre P 1995 Stress-strain model for confined high-strength concrete. J. Struct. Eng. 121: $468-477$

Eurocode 82003 Design of structures for earthquake resistance EC 8 Part 1: General rules, seismic actions and rules for buildings, prEN 1998-1

Fafitis A, Shah S P 1985 Predictions of ultimate behaviour of confined columns subjected to large deformations J. Am. Concret. Inst., 82: 423-433

FEMA 368-369, 2001 NEHPR-recommended provisions for seismic regulations for new buildings: Buildings Seismic Safety Council, (USA: Washington, D.C.)

Galeota D, Giammatteo M M, Marino R 1992 Strength and ducility of confined high strength concrete. Proceedings of the 10th World Conference on Earthquake Engineering, Madrid, Spain, A.A. Balkema, Rotterdam, Brookfield 2609-2613

Hsu L S, Hsu C T T 1994 Complete stress-strain behaviour of high strength concrete under compression. Mag. Concr. Res. 46: 301-312

IBC 2003 The International Building Code, International Code Council, Falls Church, Virginia, USA

Kent D C, Park R 1971 Flexural members with confined concrete. J. Struct. Div. ST7, 97: 1969-1990

King J W H 1946 The effect of lateral reinforcement in reinforced concrete columns. Struct. Eng., 24: 355-388

Mander J B, Priestley M J N, Park R 1988 Theoretical stress-strain model for confined concrete. J. Struct. Eng., 114: 1804-1826 
Mander J B, Priestley M J N, Park R 1998 Observed stress-strain behaviour of confined concrete. J. Struct. Eng., 114: 1827-1849

Mugurama H, Watanabe F, Iwashimizu T, Mitsueda R 1983 Ductility improvement of high-strength concrete by lateral confinement. Trans. of Japan Concrete Institute, 5: 403-410

Nagarajah R 1987 Lateral load behaviour of high strength fibre reinforced concrete columns. (Msc. Thesis) University of Nevada

Nagashima T, Sugano S, Kimura H, Ichikawa A 1992 Monotonic axial compression test on ultra-highstrength concrete tied columns. 10th World Conference on Earthquake Engineering, Rotterdam, 2983-2988

Park R, Priestley M J N, Gill W D 1982 Ductility of square-confined concrete columns. J. Struct. Div. ST4, 108: 929-950

Richart FE, Brandtzaeg A, Brown R L 1928 A study of failure of concrete under combined compressive stresses. Engineering Experiment Station Bulletin No. 185, University of Illinois, Urbana

Richart F E, Brandtzaeg A, Brown R L 1929 The failure of plain and spirally reinforced concrete in compression. Engineering Experiment Station Bulletin No. 190, University of Illinois, Urbana

Roy H E H, Sozen M A 1964 Ductility of concrete. In Flexural Mechanics of Reinforced Concrete, SP12, American Concrete Institute/American Society of Civil Engineers, Detroit, 213-224

Saatcioglu M, Razvi S R 1992 Strength and ductility of confined concrete. J. Struct. Div., 118: 15901607

Sargin M 1971 Stress-strain relationships for concrete and the analysis of structural concrete sections. Solid Mechanics Division, Study No. 4, University of Waterloo

Sheikh S A, Uzumeri S M 1980 Strength and ductility of tied concrete columns. J. Struct. Div., 106: 1079-1101

Sheikh S A, Uzumeri S M 1982 Analytical model for concrete confinement in tied columns. J. Struct. Div., 108: 2703-2722

Sheikh S A, Yeh Y Y 1990 Tied concrete columns under axial load and flexure. J. Struct. Eng., 116: 2780-2800

Soliman M T M, Yu C W 1967 The flexural stress-strain relationship of concrete confined by rectangular transverse reinforcement. Mag. Concr. Res., 19: 223-238

Yong Y K, Nour M G, Nawy E G 1988 Behaviour of laterally confined high-strength concrete under axial loads. J. Struct. Eng., 114: 333-351 